Trinity University

Digital Commons @ Trinity

Modern Languages and Literatures Faculty

Research

Modern Languages and Literatures Department

5-1993

\title{
The Desiring Subject and the Promise of Salvation: A Lacanian Study of Sor Juana's El Divino Narciso
}

Matthew D. Stroud

Trinity University, mstroud@trinity.edu

Follow this and additional works at: https://digitalcommons.trinity.edu/mll_faculty

Part of the Modern Languages Commons

\section{Repository Citation}

Stroud, M.D. (1993). The desiring subject and the promise of salvation: A Lacanian study of Sor Juana's el divino narciso. Hispania, 76(2), 204-212. doi:10.2307/344664

This Article is brought to you for free and open access by the Modern Languages and Literatures Department at Digital Commons @ Trinity. It has been accepted for inclusion in Modern Languages and Literatures Faculty Research by an authorized administrator of Digital Commons @ Trinity. For more information, please contact jcostanz@trinity.edu. 


\title{
The Desiring Subject and the Promise of Salvation: A Lacanian Study of Sor Juana's El divino Narciso
}

\author{
Matthew D. Stroud \\ Trinity University
}

\begin{abstract}
Both Sor Juana's El divino Narciso and Jacques Lacan's psychoanalytic writings deal with the nature of humankind and the nature of God. This article examines the play and its religious philosophy in light of Lacan's imaginary, symbolic, and real registers, as well as Lacan's important concepts of the Other, the divided subject, jouissance, and the death drive. Ultimately, both Lacan and Sor Juana arrive at the same conclusion, that the basis of the religious experience is grounded in the "lack" in both the subject and God, and that only death can bring the promised state of purity.
\end{abstract}

Key Words: Juana Inés de la Cruz (Sor), Divino Narciso (El), auto sacramental, Lacan (Jacques), psychoanalysis, otherness, split subject (Ichspaltung), death drive, religion, 17th century Mexican literature

$\mathbf{T}$ he overt message of Sor Juana Inés de la Cruz's El divino Narciso is quite clear: if one gives up the pleasures and pains of this life (love, sex, honor, rivalry) in favor of the duties of the Church (commandments, sacraments, responsibilities), one will be rewarded with the tranquillity of a society marked by law and order, and in the next life one will achieve ecstatic union with God. Naturaleza Humana, by submitting her desires to the commandments of God, ends the play in an apotheosis of union with Narciso, a sublimation of her nature as a human subject. Eco, on the other hand, remains unredeemed at the end, left out of the glory of the happy couple, because she was unwilling to set aside her own lust and rivalry. This moral lesson is quite typical of the religious theater of the Spanish Baroque that attempted to put forward a doctrinal whole. The modern reader, however, can look beyond the primary message to a consideration of the nature of the human subject and its relation to others, the Other, the object of desire, speech, fantasy, and death, concepts that are at the heart of the psychoanalytic writings of Jacques Lacan. Reading Sor Juana's seventeenth-century auto in the light of Lacan's twentieth century theory highlights the commonality of both texts in their understanding of the human condition.

\section{The Imaginary Register}

Central to Jacques Lacan's conception of the human condition is the notion of the divided subject. Everyone suffers from a radical split in the unconscious, a Spaltung in Freud's terminology. As a result, the subject is whole in neither essence nor behavior. To delineate the various levels on which the subject acts, Lacan created the concept of "registers" and redefined common terms to denote them. The "imaginary" register is the result of the "mirror stage" through which everyone passes as an infant. By viewing itself in a mirror, or in the mirrorimage that others provide, the subject learns jubilantly that it is a unified whole and, despairingly, that it is constructed around a lack, an inability ever to unite with others. The response of the subject to this devastating revelation is the identification with imagos that give one the illusion of wholeness, of autonomy, of power. The imaginary is the locus of the ego and of relationships between subject and object in which the subject is really involved only with its own desires that it finds echoed to it from the object. ${ }^{1}$ It is also the register of rivalry, deception, and ego defenses.

The world of the characters at the beginning of the El divino Narciso is marked by intense imaginary activity. The basic plot structure is that of the rivalry for Narciso between 
Eco and Naturaleza Humana, a relation that is described as "rencor," "pena," "odio mortal," and "rabiosa queja" $(657-60),{ }^{2}$ in short, jealousy (see, for example, 230ff., 1891-94). To try to seduce Narciso while foiling Naturaleza Humana's identical plan, Eco invents deceptions and tricks so that her rival might appear unattractive or distorted to Narciso (413-23, 622-28) or, even better, so that Narciso might never lay his eyes on her again (453-54, 17012) and that he will forget her entirely (17069). At the heart of Eco's desperate measures is a desire on her part to conquer, to eliminate not only her rival but, when he rejects her, Narciso as well. It is a struggle to the death, the fundamental characteristic of human relations in the imaginary register (Lacan, Séminaire III51), as we see in Eco's words:

con declarados odios

tengo de procurarte

la muerte, para ver

si mi pena implacable

muere con que tú mueras,

o acaba con que acabes. (813-18)

In addition, she is filled with pride and self-love (301-15; see also 641-42), both of which appear as characters just to underscore the theme.

Illustrating Lacan's psychoanalytic theory, the action of the play is structured by images of mirrors (1981-85) and of the similarities between subjects that lead to the rivalries and deceptions just enumerated. Stephanie Merrim (112) has noted the various "layers of mirroring" present in the play, not only in the basic plot line involving narcissistic reflection and the love of similarity, but also between the loa and the play, Christianity and non-Christian religions, and truth and fiction (allegory). Eco's specular relation with others is obvious even in her name, which recalls a basis in reflection and identity. Likewise, we are told that Naturaleza Humana is made in Narciso's image (455-56; cf. 215), a concept made concrete when Eco notes that Naturaleza Humana's is the reflection that Narciso sees when helooks into the pool of water:

\footnotetext{
su misma semejanza contemplando

está en ella, y mirando

a la Naturaleza Humana en ella.(1318-22)
}

When one asks the often repeated question, “¿Qué es lo que miro?”, the answer is most often the image of one's own desires. In the pool of water, Narciso sees an other with which he wants to be joined and he sees himself simultaneously in the same place. When Eco, hearing Narciso, asks the same question (1306), she sees the object of her demand for love who does not see her: there is no specular imaginary relationship here, only the one between Eco and her fantasy of union with Narciso, which is doomed to fail (see also 1318).

This specular relationship is closely related to the more general concept of love, which is both based in and sustained by imaginary identifications, at least in part. ${ }^{4}$ With its connection to ego defenses and rivalries, love produces effects typical of imaginary anxieties, as Naturaleza Humana indicates:

\author{
Mi imagen representa \\ si Narciso repara, \\ clara, clara; \\ porque al mirarla sienta \\ del amor los efectos, \\ ansias, deseos, lágrimas y afectos.(1113-18)
}

The imaginary manifestations of love are a function of the subject's desire for an other, an object, that will make it whole. This passion is part of the human condition, a characteristic of being "hombre no más" (683), and references to hunger and thirst are frequent, as when Naturaleza Humana says that she hungers for God just as she hungers for her own center (110-11), an incontrovertible reference to the search for an object that will make her feel complete. When Gracia tells Naturaleza Humana to find clear waters (like a mirror) in order to wait for Narciso to slake the thirst that burns in him (1024-77), we see in her words not only the specular nature of desire, at least on one level, but also the fantasy of fulfillment in the hope that the thirst can be quenched:

\footnotetext{
...vuelve tú la imagen clara

de la beldad de Narciso,

que en ti sola se retrata

con perfección su belleza,

sin borrón su semejanza!(1054-58)
}

The imaginary promise is always one of 
wholeness, whether it is expressed in terms of power, of absolute independence, or of a consuming love, as Eco implies:

Todo, bello Narciso, sujeto a mi dictamen, son posesiones mías, son mis bienes dotales.

Y todo será tuyo,

si tú con pecho afable

depones lo severo

y llegas a adorarme.(795-802)

The subject hopes that this happy promise can fulfill its wishes; Naturaleza Humana anticipates the joys of love:

...y logra mi deseo

las alegres promesas amorosas... .(887-88)

While specular love appears to require reciprocity, as when Naturaleza Humana declares her intention to "solicitar los amores / de Dios" (121-22), actually, as Gracia states, there is little difference between love of one's self and love of one's mirror image:

viendo en el hombre su imagen,

se enamoró de sí mismo.

(2019-20; see also 460-64, 1543)

Because of the egoistic short circuit in which it is trapped, love in the imaginary, and the imaginary register in general, are incapable of fulfilling the demands of the subject, as Narciso notes:

Mirando lo que apetezco,

estoy sin poder gozarlo... (1454-55).

The frustration caused by incompletion and insatisfaction results in effects that go beyond the jealousy and rivalry already mentioned to suffering, hate, ${ }^{5}$ and metaphorical death:

Ya, ya llego,

al término fatal por mí querida....

(1602-3; see also 1742-54)

Since the imaginary register is bound up only in the connections between an insatiable ego and impossible objects, all efforts to achieve any kind of satisfaction are, as Eco says, "en vano" (see 428-38); like Naturaleza Humana, one feels alone and helpless (1797); "olvidado de si" (674). Every subject in the imaginary is caught in an egoistic short circuit that not only prevents satisfaction by the other but even precludes the possibility of any kind of real relationship. ${ }^{6}$ The specular nature of the love between Narciso and Naturaleza Humana is not guaranteed by any external truth. Its instability is made apparent when Eco clouds the waters (with sin), destroying the reflection (622-28).

\section{The Symbolic Register}

As the play warns, the hoped-for wholeness and unity simply cannot be attained through self-love and egoistic action, that is, through the imaginary register alone (1574-76). In order to reach out to others, the subject must first have access to, and subordinate itself to, a third term that will provide an interface between two subjects: symbolization, language, the law, the Other, all of which comprise Lacan's "symbolic" register. ${ }^{7}$ The law, as we are told by Sinagoga and Gentilidad (40-41), should be written on the hearts of all people to warn them of the dangers of the imaginary rivalry to the death. Without the law, one lives in error. The symbolic promises a guarantee of objective truth offered in the terms of the play by the Church (37-38). This truth is seen to be something almost tangible that resides in the Other who is supposed to know (see Lacan, Écrits 94-96). One expects, even demands, the truth from the Other, and Narciso, in his role as the son of God, reassures Naturaleza Humana of his "inmensa / sabiduría" (1934-35).

Speech is the agency that both structures and allows access to the symbolic register. ${ }^{8}$ Only through speech can subjects come together to agree on anything at all. A healthy human subject is just that only insofar as it can speak. In the terms of the play, Eco's symptom, her speech dysfunction, her ability only to repeat the last words said to her (1332-59, 1390-1439, 1471-1602), is a concrete example of her failure to submit to the signifier, the symbolic. Throughout the play, there are references to both speech and silence, writing and erasure (264-66, 575-76, 669-70, 133259, 1660, 1715-18, 1967-68). Indeed, Jane E. Ackerman has stated that the play has one focus: "the efficacy of the Word" (63). It is pre- 
cisely the accession to language, the insistence of the signifier in the subject, that constitutes the subject, the subject that cannot reach its objectexcept through language, the subject denoted by its failings, as we see in Naturaleza Humana's complaints of incompletion (201-40 and 1797-99).

The role of the symbolic father (as opposed to the real or any other kind of father) is essential in the necessary functioning of the structuring signifier of the unconscious, which Lacan calls the "phallic signifier" or, metaphorically, the "Name of the Father." In the play, the figure that embodies the symbolic register is God the father. His is the name that we are to praise eternally (6-7, 2146). His power functions both directly and through intermediaries such as the Church, represented here as Sinagoga $(7,42)$. God is the representation of the Other as father, the dead father, the powerful father, king forever (539, 547, 1221, 895-96, 1873-74; see Regnault $46-47,61-62)$. His is the name invoked when one appeals to the Other for help (545). His promise, as Narciso tells us, is to give the subject "remedios a sus peligros" (1905), to be there for the subject whenever it needs Him (1979-21). Perhaps the clearest example of the symbolic mediation of desire is the institution of marriage. Eco and Naturaleza Humana both lust after Narciso; both believe they can fulfill their desires for him by being his wife $(385-86)$. This concept of symbolic union is reminiscent of the Platonic notion of the nostalgia for a primordial union with the One, to which Eco alludes when she says that Narciso contains sparks of the first origin which the noble being remembers (528-30). Only Naturaleza Humana, however, actually submits her passion to the symbolic, gives herself over to the sacrament (2127): she becomes Narciso's spouse $(1296,1865)$.

For a fully functioning, speaking human subject, one's desire is the desire of the symbolic Other, in both of its potential meanings: one's desire is the desire for the Other, and one's desire is the Other's desire (Lacan, Écrits 312). Narciso is the attractive object of desire (83-101, 399-400, 413-23, 819-20, 1849), able to seduce even the rocks and mountains (194-98), the lure that entraps the egos of Eco and Naturaleza Humana in a web of love and rivalry (182-84).$^{10} \mathrm{He}$ is the target of Eco and Naturaleza Humana's feminine wiles: they try to get him to desire them as much as they desire him (121-22). ${ }^{11}$ In addition to being the desired object, he is also the desiring subject, whose passion, like Naturaleza Humana's, is expressed in terms of hunger and thirst $(1232,1235)$. In a theatrical representation of the desire of the Other which is both the cause and the object of the subject's desire, Narciso, at the same time that he is sought by Natura-leza Humana, likewise seeks her out as a shepherd looks for a lost sheep (1133-36, 1147-50). That he engages actively in the imaginary love triangle is seen not only in his obviously specular (narcissistic) relationship with Naturaleza Humana (1543), but also, as was the case with Eco, in his very name. As a member of this imaginary relationship, he is by no means exempt from the egoistic actions and thoughts typical of a lover (1211-20,1486-88). Although one might wish to escape the imaginary for the promise of the symbolic, one can never leave behind the imaginary register. There is no actual progression from the imaginary to the symbolic; the subject is always engaged in both.

\section{The Real Register}

According to Lacan, all speaking subjects always hope that the Other will be able to fill the gaps, to replace, or at least cover over, the object that is missing, the objet $a$ that "falls out" at the moment of the original splitting of the subject. This object, and the lack created by its omission, although they produce important effects in both the imaginary and symbolic registers, are themselves part of a third register, the "real," impossible to attain and inaccessible in any direct way in either the imaginary or the symbolic (Lacan, Écrits 195-96, $286,296,319-20)$. A case could be made for the equation of this division of the subject, its irrecoverable separation from the Other, and original sin. In this case, the sin is not in having been born, as Calderón said in La vida es sueño, but in being divided by submitting to the Name of the Father, a religious tautology in which God in essence causes the failure of 
the subject. It is the decentered nature of the human being that causes the "errors" in both the imaginary and symbolic registers: one way or another the human subject is always looking for something to fill the gaps at its core (Lacan, Seminar II, 160, 326). But because the lack is inherent to the human condition, the symbolic promise to span the gap and recover the lost object is not only doomed to failure, it also has significantnegative consequences. It promises satisfaction, but in return for the sacrifice of individual ego demands. Submission to the Other is accompanied by an enormous sacrifice of the self as in the example of God's commandment to Abraham to kill Isaac (551-62) as a sacrifice to the law. The subject fades before the primacy of the signifier. In fact, there is no subject without fading, or aphanisis, as soon as the subject "appears somewhere as meaning, he is manifested elsewhere as 'fading,' as disappearance". ${ }^{12}$ One must give up the pleasure of the ego (the image of autonomous unity) for the assurances of law and order. Moreover, the promise is not open-ended: Eco tells us that Narciso is of such a nature that, if one offends him even once, one cannot return to grace (428-30), and, even if one accepts the offer, "nadie es capaz / de satisfacerla” (431-32).

More importantly, the Other itself is not whole; there is no Other of the Other, no guarantee of the absolute, objective truth that the subject demands of the Other; the symbolic simply cannot fulfill its promise of completion. ${ }^{13}$ Truth, in psychoanalysis, resides in the desire of the subject, which is in turn desire of the Other. If God represents the Other, then saying that God represents the truth at one and the same time puts God in the locus of truth but only insofar as He constitutes the subject's desire for the impossible object. The truth that we want the Other to guarantee is always relative to the desires of the subject that asked for it, desires that spring from the subject's incompletion. Lacan has noted that the usual ways in which one looks for truth and wisdom are functions of mastery, of the ego, that are related to what he calls the "paranoiac principle of human knowledge" (Écrits 138). Because one is always separated from any "objective" truth of the world by imperfect systems of perception and interpretation, and because there is no error that is not posed as truth, the only certain truth in a psychoanalytic sense lies in the subject's desire (see Lacan, Seminar I, 168, 263; Ragland-Sullivan, "Magnetism" 385, 392).

Even language, the basis of symbolic mediation, is itself uncertain, changing, shifting, deficient, as we see in Naturaleza Humana's assertion:

una cosa es la que entiende

y otra cosa la que oye. (154-55, see also 502-6)

Since the Other can provide no absolute guarantee, the signifiers are constantly sliding, causing speech to be always relative (Lacan, Écrits 154). Because of the subject's constitutive relationship with the Other, direct communication with another subject is, in a very real sense, impossible; one's message is returned to the sender but inverted (Lacan, "Seminar on "The Purloined Letter" 72). The clearest example of the failure of language is Eco's dysfunctional speech. ${ }^{14}$ For Merrim, this destabilizing use of language demonstrates Eco's ability to "wrest others' words from their original context and oblige them to serve her own purposes" as well as her inability to speak except by "figuring others' words" (114).

The consequences of incompletion that we see in matters relating to truth, language, love, and the subject become even more problematic and interesting with regard to the nature of God. God is supposed to be the omnipotent father, the author of law, the guarantor of the universe. But He, as the Other, cannot be a unified whole. He is not all-powerful and allencompassing: the devil also has power, and His creatures have the free will to reject Him. $\mathrm{He}$ is not all. The benefit of His incompletion is that, unlike the perfect "philosopher's God," $\mathrm{He}$ is therefore able to have a personal, intersubjective relationship with His creations (see Regnault 32-47). The clearest example of this quality of not-all is His division into three: father, son, and holy spirit (see 156-59, $326,351,2146)$. God the father has no significant theatrical role in the play, but we can see the consequences of His incompletion in the character of His son, Narciso, who, as we have seen, suffers from the same divisions, the 
same imaginary relationship, the same desires as do Eco and Naturaleza Humana. At the same time, he is also the son of God (1675), the incarnation of the Other, Christ who died so that our sins might be mediated (2087-2100). His roles are doubled (and perhaps tripled): Narciso's handsomeness is an imaginary lure, but, since he also represents the Other, his lack also serves as a lure because it is in that unsymbolized place in the Other that the subject finds the outline of its lost and irrecoverable object a. Narciso maintains his love relationships, but he also wishes to hide his face from his flock:

Yo esconderé mi cara...

de este ingrato, perverso, infiel ganado.

$(1202,1205)$

Later on, he tells Echo not to hope to see his eyes (1590) and Naturaleza Humana not to touch him (1872). One is specifically forbidden from looking upon the face of God; to see the face of God is to die. The phallic signifier must remain veiled (Lacan, "Desire" 48 ).

The disunity of his character is clearly indicated by the text of the auto. Eco realizes that Narciso is the son of God and notes that he was born to a "verdadera mujer" (603-4), and perhaps we may conclude that he inherited his complex nature from his mixed parentage. Even in his aspiration to perfection in the Other, he will always carry with him the part that comes from the real woman, that is, he can never be whole on that account. At the same time, he is not just an object of Naturaleza Humana's desire, he is an imago that structures her identity: his image is in her (215). When he says that he is "soberano" (1221), it is simultaneously an assertion of his imaginary wholeness and the supposed omnipotence of the Other. God, the Other, is also Narciso, the other. Narciso's actions both as a subject in his relations with Eco and Naturaleza Humana and as the Other in his divinity cause us to question the harmonious unity posited by the message of the play.

The action follows a trajectory toward an apotheosis of unity. There is a clear indication that God supposedly moves from not-all, from being able to have an intersubjective relation with the subject, to a totalizing, and totalized perfection, and that the subject is carried away and made one with the Other (and, in the process, lost as an individual subject), as in the marriage of Naturaleza Humana and Narciso at the end (1299). Naturaleza Humana is like every subject: when she calls to the Other, she wants the Other to respond as the omnipotent, all-seeing, all-knowing God who will fill in the lack at the core of her being..$^{15}$ But we have seen that the auto has structured the characters of God and Narciso as divided speaking subjects unable to fulfill the promise of completion for Eco. While she is indeed abandoned because of her unwillingness to submit to the law, God's grace, which no one can earn by any symbolic means, is also applied unevenly: Gracia embraces Naturaleza Humana but Eco is not offered the same benefit. ${ }^{16} \mathrm{By}$ juxtaposing the offer of salvation and the incompletion of God, El divino Narciso shows up the basic flaw in the symbolic promise: one must already be inscribed in the symbolic in order to hear its promise; in order for God to offer salvation, one must first have already accepted it by believing in Him. In light of the inability of either the imaginary or the symbolic to fulfill their promises of wholeness, this unity, and, indeed, the message of the play itself, can only be seen as the fantasy of the subject.

\section{The Death Drive}

That God is an object of fantasy shows that, in asking for completion from God, one asks not just for symbolic mediation or imaginary love, but a jouissance that goes far beyond any comfort provided by the other two registers, to the register of the real, and leads us to a direct confrontation with death. Jouissance is not pleasure in the normal, conscious meaning of the term. In fact, the experience of it in the real is quite unpleasant. Rather, joussance is the unconscious celebration of the lack of the subject, of the Ichspaltung, closely related to hysteria, psychosis, and the death drive (Lacan, Écrits318-20, "Kant”60-61,95n). The closer one gets to God, the more one approaches jouissance (Ragland-Sullivan, "Dora" 213, 216, 219, 222-23, 225; Regnault 101, 108). Complete unity with God, as the mystics de- 
scribed it, would go beyond whatever the symbolic can offer to an impossible ex-stasy, a being outside of one's being, and, of course, the disappearance of the subject itself. Lacan termed this state plus-de-jouir, an excess and a cessation of jouissance at the same time (Lacan, Feminine 144-45). Thus, union with God implies the death of the subject, which is in a real sense absolute jouissance, a plusde-jouir. This is the ultimate expression of Christian desire.

Even though Naturaleza Humana uses some of the discourse of mysticism ("mi divino amado,"939), this play is not mystical: there is no conjoining of the two entities except in a symbolic, metaphorical sense (marriage). Still, when Narciso looks for Naturaleza Humana as a lost sheep, he says that he would rather die than give up the search (1162-65). He says specifically that it was love that made mortal him who was immortal (1496-99, see also 1742-54, 2033-38). The Other as an abstraction, the perfect, non-existent Other that is supposed to resolve the subject's misery, that may be conceived of as independent of the subject, is immortal, but once it partakes of human subjectivity, it too is subject to mortality. When Narciso dies, sin is forgiven: "se borran nuestras ofensas" (66970). Narciso's goal is death ("bajé a morir," 1548), which is both symbolically metaphorical of imaginary pain, and captions the death drive in the real. As Narciso points out, death should be the end of sin, the end of suffering, the end of mortality, the end of the subject's division:

\footnotetext{
Ya licencia a la muerte doy: ya entrego el alma, a que del cuerpo la divida, aunque en ella y en él quedará asida mi deidad, que las vuelva a reunir luego.

Sed tengo: que el amor que me ha abrasado, aun con todo el dolor que padeciendo estoy, mi corazón aún no ha saciado.

¡Padre! ¿Por qué en un trance tan tremendo me desamparas? Ya está consumado. ¡En tus manos mi espíritu encomiendo!(1606-15)
}

Like Naturaleza Humana, Narciso views his union with his Father in terms of a fantasy to be crossed. In this regard, this union is perfect ecstasy in all registers, but one can only achieve this ex-stasy in death. When the sub- ject dies, its structuring signifiers, its relation to the Other, and the promises of wholeness, die in their fulfillment. The life of the subject is therefore little more than "a defect in the purity of Non-Being” (Lacan, Écrits 317); through death, salvation is a return to purity.

\section{Conclusion}

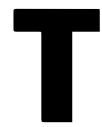

he splitting of the human subject and its relationship to the Other is not just a fictional construct of twentieth-century psychoanalysis. The metaphysical, mystical characteristics of Golden Age theology also leave no doubt about their understanding of the divided nature of the human subject and its relation to God. Just as the human being is not complete within its being, neither is God rational, distant, perfect, and uninterested. Each participant in the relationship must necessarily be lacking in some area to which the other can appeal, but that very lack undermines the promise made. Christian theoreticians have given considerable thought and importance to the lack of unity in the concepts of God, namely the fact that one man, Jesus Christ, could have both divine and human natures, while God Himself has three manifestations (father, son, holy spirit). ${ }^{17}$ Enormouspsychoanalytic intuition is at work in the religious theater of the Golden Age, whether in the comedia or in the auto sacramental. As Henry Sullivan has noted $(613-14,617)$, Calderón's view of the human subject seems to anticipate modern psychoanalysis, not so much in clinical practice with its emphasis on the individual unconscious, but paradigmatic psychoanalysis with its ability to tell us something about the human subject in general. Sor Juana, too, seems to share Calderón's vision of the human condition, and El divino Narciso provides a case study of the paradigmatic role of psychoanalysis in literary texts. In their rejection of Cartesian certainty and the illusion of wholeness, pre-modern literature and postmodern theory converge in their study of the human subject.

\section{nOTES}

${ }^{1}$ Lacan's discussion of the mirror stage appears as 
the first selection in Écrits: $A$ Selection, 1-7. For overviews of Lacan's definitions of the imaginary register, see Lee (17-30) and Ragland-Sullivan, Jacques Lacan (130-59).

${ }^{2}$ The standard edition of Sor Juana's works is the 4volume Obras completas edited by Alfonso Méndez Plancarte (México: Fondo de Cultura Económica, 1955). The line numbers for El divino Narciso are unfortunately in error above line 909 . As a result, the citations here are from Ripoll and Valdespino's anthology. Except for occasional punctuation and capitalization differences, the text is identical to that found in the Obras completas.

${ }^{3}$ See also 251-54. Naturaleza Humana is an even more interesting figure than the normal allegorical characters of autos sacramentales. Not only is she at once both concept and personification, there is also her role as mother, the "madre / común de todos los hombres" (28-29). Although it is beyond the scope of this study, another fruitful approach to this play might be in terms of the mother as "the real Other of demand, whose desire (that is, her desire) one wishes she would assuage..." (Écrits 321).

${ }^{4}$ Love in the imaginary is fundamentally a narcissistic illusion and is closely related to the ego ideal (Lacan, SeminarI, 112, 126, 142, 180), but love depends on more than just the imaginary: "No love can be functionally realisable in the human community, save by means of a specific pact, which, whatever the form it takes, always tends to become isolated off into a specific function, at one and the same time within language and outside of it. That is what we call the function of the sacred, which is beyond the imaginary relation" (174; see also 217 , 276-77).

${ }^{5}$ As Eco says, "en odio trueco el amor" (403). One finds love at the juncture of the symbolic and the imaginary, while hate lies at the intersection of the imaginary and the real (Lacan, Seminar I, 271; see also 276-77). When the symbolic fails to hold, imaginary rivalries and defenses take over.

${ }^{6}$ See Lacan, Écrits 307. Merrim (113) describesEco's role as that usually assigned to the devil in the auto sacramental, and suffering from the same loss of resemblance that Lucifer did upon his fall.

${ }^{7}$ For a general discussion of the symbolic, see Ragland-Sullivan, Jacques Lacan, 130-37, 145-83.

${ }^{8}$ The importance of speech to the subject, and the essential relationship of speech and the symbolic, is discussed directly in "The Function and Field of Speech and Language in Psychoanalysis" in Ecrits. See in particular pages 56-77; see also 125, 285-86, 305.

${ }^{9}$ See Lee 64-67; Ragland-Sullivan, Jacques Lacan, 55, 305 . Regnault deals with the paternal metaphor in a specifically religious context on $61-62,91,95,100$.

${ }^{10}$ See also 323-28. For Lacan's discussion of sight, the gaze, and the lure, see Four Fundamental Concepts $93,102-03$.

${ }^{11}$ There is something of masquerade here, a reference to feminine sexuality that is more capable of the mystic experience of unity with the Other and the accompanying jouissance than is the masculine. This masquerade will serve as a lure to capture God in the imaginary realm of love. See Lacan, Écrits 289-91; Safouan 110.

${ }^{12}$ Lacan, Four Fundamental218, 221. See also Lacan, "Of Structure" 194, and Feminine 35, 94, 104, 120; Lee 146-54; MacCannell 13.

${ }^{13}$ Lacan, "Desire" 25; Écrits 195, 311; Feminine 168. See also MacCannell 55, 68, 81.

${ }^{14}$ Merrim (114) has noted the similarity with a technique of Athanasius Kircher by which one forms new words by removing one or two letters from the previous word (clamore, amore, more, ore, re). Octavio $\mathrm{Paz}$ has dealt at some length with the influence of Kircher on Sor Juana. He notes that the idea to cast Christ as Narcissus shows an "extraordinary similarity" to the first section of the Corpus Hermeticum, and he suggests that Sor Juana might have been inspired by Kircher's version (462-64). Imanol San José Azueta agrees, adding that the particularversion of the Narcissus myth that Sor Juana must have followed came not from Ovid but from Pausanias (115-19).0

${ }^{15} \mathrm{Cf}$. Lacan, Écrits 320 : "Only my formulation of phantasy enables us to reveal that the subject here makes himself the instrument of the Other's jouissance."

${ }^{16} \mathrm{Although}$ Gracia is a character in this auto, her role is not doctrinally important. While grace is called "la mejor prenda del alma" (1007-8), Gracia mainly serves here to inform Naturaleza Humana about what she is doing and should do, and at one point the two characters are placed on stage in such a way as to appear to be looking at each other, yet another instance of specular identification. See also 1131ff., 961-68, 2023-24.

${ }^{17} \mathrm{On}$ both the hypostatic union and the nature of the Trinity, especially in relation to Calderón's El diablo mudo, see Dietz "Theology" 98, 102-4. Concerning the allegorical representation of God as three different characters in Calderón's auto, La vida es sueño, see Dietz, “Conflict" 180-81.

\section{口 WORKS CITED}

Ackerman, Jane E. "Voice in El divino Narciso." Bulletin of the Comediantes 39 (1987): 63-74.

Cruz, Sor Juana Inés de la. El divino Narciso. Teatro hispanoamericano: Antología Crítica. Ed. Carlos Ripoll and Andrés Valdespino. 2 vols. New York: Anaya, 1972. 1: 223-66.

Dietz, Donald T. "Conflict in Calderón's Autos Sacramentales." Approaches to the Theater of Calderón. Ed. Michael D. McGaha. Lanham, MD: University Press of America, 1982, 175-86.

"Theology and the Stage: The God figure in Calderón's Autos Sacramentales," Bulletin of the Comediantes 34 (1982): 97-105.

Lacan, Jacques. "Desire and the Interpretation of Desire in Hamlet." Literature and Psychoanlysis. The Question of Reading: Otherwise. Ed. Shoshana Felman. Baltimore: Johns Hopkins UP, 1982, 11-52.

Écrits: A Selection. Trans. Alan Sheridan. New York: Norton, 1977.

Feminine Sexuality. Ed. Juliet Mitchell and Jacqueline Rose. Trans. Jacqueline Rose. New York: 
Norton, 1982.

The Four Fundamental Concepts of PsychoAnalysis. Ed. Jacques-Alain Miller. Trans. Alan Sheridan. New York: Norton, 1978.

. "Kant With Sade." Trans. James B.

Swenson, Jr. October 51 (Winter 1989): 55-104.

. "Of Structure as an Inmixing of an Otherness Prerequisite to Any Subject Whatsoever." The Structuralist Controversy: The Languages of Criticism and the Sciences of Man. Ed. Richard Macksey and Eugenio Donato. Baltimore: Johns Hopkins UP, 1972, 186-200.

. Le Séminaire. Livre III: Les Psychoses. Ed. Jacques-Alain Miller. Paris: Seuil, 1981.

. The Seminar of Jacques Lacan. Book I:

Freud's Papers on Technique 1953-54. Ed. JacquesAlain Miller. Trans. John Forrester. New York: Norton, 1988.

The Seminar of Jacques Lacan. Book II: The Ego in Freud's Theory and in the Technique of Psy choanalysis 1954-1955. Ed. Jacques-Alain Miller. Trans. Sylvana Tomaselli. New York: Norton, 1988. ."Seminar on The Purloined Letter." Trans. Jeffrey Mehlman. Yale French Studies 48 (1972): 3872.

Lee, Jonathan Scott. Jacques Lacan. Twayne World Authors Series 817. Boston: G. K. Hall, 1990.

MacCannell, Juliet Flower. Figuring Lacan: Criticism and the Cultural Unconscious. London: Croom Helm, 1986.
Merrim, Stephanie. "Narciso Desdoblado. Narcissistic Stratagems in El divino Narciso and the Respuesta a Sor Filotea de la Cruz." Bulletin of Hispanic Studies 64 (1987): 111-17.

Paz, Octavio. Sor Juana Inés de la Cruz o Las trampas de la fe. Barcelona: Seix Barral, 1982.

Ragland-Sullivan, Ellie. Jacques Lacan and the Philosophy of Psychoanalysis. Urbana: U of Illinois P, 1987. "Dora and the Name-of-the-Father: The Structure of Hysteria." Discontented Discourses. Feminism/Textual Intervention/Psychoanalysis. Ed. R. Feldstein and M. Barr. Urbana: U of Illinois P, 1989, 208-40.

. "The Magnetism Between Reader and Text:Prolegomena to a Lacanian Poetics." Poetics 13 (1984): 381-406.

Regnault, François. Dieu est inconscient. Paris: Navarin, 1985.

Safouan, Moustapha. La Sexualitéféminine dans la doctrine freudienne. Paris: Seuil, 1976.

San José Azueta, Imanol. "Sobre una posible influencia hermética en El divino Narciso de Sor Juana Inés de la Cruz." Letras de Deusto 19: 43 (1989): 109-20.

Sullivan, Henry W. "Psicoanálisis paradigmático en los autos sacramentales de Calderón.” Actas del VIII Congreso de la Asociación Internacional de Hispanistas. Ed. A. David Kossoff, José Amor y Vázquez, Ruth H. Kossoff and Geoffrey W. Ribbans. 2 vols. Madrid: Ediciones Istmo, 1986. 2: 613-17. 